\title{
Perception and Perceived Experiences about Prevention and Consequences of Teenage Pregnancy and Childbirth among Teenage Mothers: A Qualitative Study
}

\author{
Sushila Devi Bhandari ${ }^{1}$, Sarala Joshi ${ }^{2}$ \\ ${ }^{1} \mathrm{PhD}$ Scholar, Mewar University, Rajasthan, India \\ ${ }^{2}$ Assistant Dean, Institute of Medicine, Coordinator of PhD Program, Nursing Campus, \\ Maharajgunj, Kathmandu

\section{Corresponding author} \\ Nepalese Army Institute of Health Sciences, College of Nursing, Kathmandu, \\ ya_su_sa@hotmail.com, \\ Mobile: 9841422518
}

\begin{abstract}
Teenage pregnancy and childbirth is a social problem in many Asian countries including Nepal. Many quantitative studies have been done on teenage pregnancy, its outcomes, and challenges faced by teenager, but very little are known about their perceptions and experiences about teenage pregnancy and their consequences during childbirth. This study aimed to explore the perceptions and experiences of teenage pregnancy and childbirth among teenage mothers. This study has adopted phenomenology approach to explore the perceptions and experiences of being a teen mother. Study was based on data collected through in-depth interviews (IDIs), and Focus Group Discussion (FGDs). All respondents provided verbal as well as written consent to face the interview. IDI guide was used to collect information among teenage mothers to assess their perception and experiences on teenage pregnancy and childbirth. Similar guide was used for FGDs. Collected information was manually processed through qualitative content analysis and grouped into theme and subthemes. The teenage mother understood that teenage pregnancy and childbirth is a risk for both mother and child. A majority of them perceived that low education, poverty, love marriage, family problems, inlaws pressure; cultural prospects are aggravating factors leading to teenage pregnancy. Almost all of the respondents mentioned the negative impact of teenage pregnancy on the health. But very few respondents knew advantages of teenage childbirth. Most of them however knew that the teenage pregnancy can be prevented. Access to family planning services to teenage mothers, community awareness, and government support is needed to reduce teenage pregnancy and childbirth.
\end{abstract}

KEYWORDS: experiences, perceptions, health effects, teenage Pregnancy

\section{INTRODUCTION}

Globally, 16 million adolescents give birth each year covering $11 \%$ of births. $95 \%$ of these births occur in low and middle income Countries (WHO, 2008 a). Teenage girls who give birth 
ISSN: 2362-1303 (Paper) | elSSN: 2362-1311(Online)

JOURNAL OF ADVANCED ACADEMIC RESEARCH (JAAR)

Jan 2016

each year have higher risk of dying from maternal causes than young adults (WHO , 2008 b). In addition teenagers below 16 years face four times higher risk of maternal death compared to women over 20. Likewise, babies born to adolescents also face a significantly higher risk of death (Paranjothy, 2009).

In Nepal about 1 in 5 girls from 15 to 19 years become mother or pregnant soon after marriage. Majority of adolescent girls get married and are pressurised to have a child (UNFPA, 2013). The main cause of teenage pregnancy in South Asia was reported to be poor socio-economic status, low educational achievement, cultural taboos and family structure (Brennan et al, 2005, p.37).

Due to teenage pregnancy and childbirth most of the teenagers were forced to discontinue their education and become dependent throughout their life. Additionally, both the teenager and her child's future become dark (Sarah \& Muthoni, 2012).

\section{General Objective:}

- To explore the perceptions and experiences of teenage pregnancy and childbirth among teenage mothers.

\section{Specific Objectives:}

- To explore the perceptions and experiences on consequences of teenage pregnancy and childbirth.

- To explore the perceptions and experiences on prevention of teenage pregnancy and childbirth.

\section{METHODS}

The data was collected from March to September 2015 in Paropakar Maternity Hospital, Nepal Medical College (NMC) Teaching Hospital, and Patan Hospital. For this study participants were selected from the hospital chart. Data was collected by using phenomenology approach to explore the perception and experiences among teenage mothers and their care givers. Total 24 teenage mothers and 24 care takers of teenage mothers were included in In-depth interviews (IDIs) and Focus Group Discussions (FGDs), respectively. For efficient data collection the researcher has managed a record keeper and digital recorder. Pre tested open ended questions were used for interview. Ethical approval was obtained from Nepal Health Research Council (NHRC) and concerned hospitals. Verbal as well as written informed consent was obtained from each respondent for interview, note taking and digital recording. 
Qualitative content analysis was done manually. The interviews were read several times to gain understanding of the text and to capture the essential meaning. Responses were classified, coded and made final report.

Table 1: Some of the example of qualitative content analysis in meaningful units, their condensation and abstraction are shown in the following table;

\begin{tabular}{|c|c|c|c|c|c|}
\hline $\begin{array}{c}\text { Respo } \\
\text { ndents }\end{array}$ & $\begin{array}{l}\text { Meaningful units } \\
\text { Natural }\end{array}$ & $\begin{array}{c}\text { Condensed } \\
\text { meaningful } \\
\text { units }\end{array}$ & Code & Subtheme & Theme \\
\hline R2 & $\begin{array}{lr}\text { Causes of teenage } \\
\text { pregnancy } \\
\text { poverty } \\
\text { ignorance }\end{array}$ & $\begin{array}{l}\text { Poverty and } \\
\text { ignorance } \\
\text { cause teenage } \\
\text { pregnancy }\end{array}$ & $\begin{array}{l}\text { Poverty } \\
\text { and } \\
\text { ignorance }\end{array}$ & $\begin{array}{l}\text { Aggravating } \\
\text { factors }\end{array}$ & \multirow{3}{*}{$\begin{array}{l}\text { Teenage } \\
\text { pregnancy } \\
\text { linked to } \\
\text { poverty, } \\
\text { ignorance, } \\
\text { Parental } \\
\text { relationship } \\
\text { and In laws } \\
\text { support }\end{array}$} \\
\hline R5 & $\begin{array}{l}\text { Family problems } \\
\text { like frequent } \\
\text { quarrelling of } \\
\text { parent effects on } \\
\text { daughter and she } \\
\text { ran away with } \\
\text { boyfriends and } \\
\text { becomes pregnant }\end{array}$ & $\begin{array}{l}\text { Frequent } \\
\text { quarrelling } \\
\text { effect on } \\
\text { teenage } \\
\text { pregnancy }\end{array}$ & $\begin{array}{l}\text { Disturbed } \\
\text { family }\end{array}$ & $\begin{array}{ll}\text { Cause of } \\
\text { teenage } \\
\text { pregnancy }\end{array}$ & \\
\hline R6 & $\begin{array}{l}\text { In laws interest to } \\
\text { see grandson also } \\
\text { one of the cause of } \\
\text { teenage pregnancy }\end{array}$ & $\begin{array}{l}\text { In laws } \\
\text { pressure to see } \\
\text { grandson }\end{array}$ & $\begin{array}{l}\text { In laws } \\
\text { pressure }\end{array}$ & $\begin{array}{l}\text { Aggravating } \\
\text { factors }\end{array}$ & \\
\hline
\end{tabular}

Source: Graneheim \& Lundman, 2004

\section{RESULTS}

The average age of teenage mothers was $17.08 \pm 1.52$ years. One third of the respondents $33 \%$ were from Tamang community followed by $17 \%$ from Magar and Newar communities respectively. Almost all of the respondents of IDIs and FGDs perceived teenage pregnancy as risk for both mother and baby and reported that the trend of teenage pregnancy is still very high because of liberty and easy access of communication.

...Trend of love marriage is increasing because of easy access in communication system. Easy access of mobile and internet increase the communication among boys and girls and they fall in love and get married without parents' consent. After marriage they get pregnant. (FGDs) 
ISSN: 2362-1303 (Paper) | elSSN: 2362-1311(Online)

JOURNAL OF ADVANCED ACADEMIC RESEARCH (JAAR)

Most of the respondents considered poverty and family problems as major causes of teenage marriage and pregnancy.

My mother and father always have dispute and they didn't have good relationship. They always scold us without any reason and they don't want to send us to school. This is all because of poverty. One day my boyfriend asked me to elope and after we eloped I got pregnant... (IDI R17)

Both the respondents of IDIs and FGDs perceived that the cause of teenage pregnancy is associated with pressure from in laws.

.......My in laws believe if they see the face of their grandson they will directly go to heaven after they die.......(IDI R22)

...Some of the in-laws think giving birth to a child in early age means continuation of their generation and they feel happy... (FGDs)

Most of the respondents realized that large numbers of daughters in families was also a cause of teenage marriage and pregnancy.

........ I have 4 sisters and one brother. My parents think that their reputation is at stake by keeping their daughters unmarried as there is a high probability of them running away with boyfriend which is why they get them married at an early age......(IDI R9)

Most of the respondents thought that parents' education level, respondent's own education, early marriage and ethnicity are the causes of teenage pregnancy.

I am from Tamang community and in my community most of my sisters and neighbours get married at an early age without parents' consent........... So I also got married without consent and got pregnant...(IDI R7)

One of the respondents understood violence is one of the main causes of teenage pregnancy.

I was raped by my neighbour frequently and I couldn't express this problem to anyone. One day I got pregnant and my mother menstruation was stopped and my mother asked me why you didn't have cycle, anything wrong with you, and then I cried and exposed the reality to my mother.... (IDI R24)

\section{Consequences of Teenage pregnancy}

Very few participants perceived teenage pregnancy and childbirth as advantageous.

We are staying in a joint family and my in laws will take care of my baby so I don't have to worry about taking care of the baby (IDI R18)

When I saw the baby for the first time, it was a wonderful experience and it bought happiness in my life and motivated me to be a responsible person for the sake of the child......(IDI R6) 
ISSN: 2362-1303 (Paper) | elSSN: 2362-1311(Online)

JOURNAL OF ADVANCED ACADEMIC RESEARCH (JAAR)

Jan 2016

Most of the FGDs respondents perceived that the teenage pregnancy and childbirth may increase divorce rates in future.

After pregnancy and childbirth teenage girls can't continue their education but boys do not face such problem so continuing their education they later are able to hold a good position in the office and society. Now the difference in the education level and status creates a gap between husband and wife and then unfortunately leads to divorce. (FGDs)

\section{Health effect on mother:}

Almost all of the respondents perceived negative impact of teenage pregnancy and childbirth on health of mothers. Some of the respondents faced problems and shared that they might encounter some other problems in the future.

..I have had prolonged labour and my baby had difficulty in breathing, therefore I had undergone surgery (Caesarean Section) I think this is because of teenage childbirth (IDI R8)

I had prolonged labour of about 16 hours and had extended episiotomy.......... My wound was not healed and got infected...... Because of the infection, I had to stay in hospital more than a week and needed to spend more money for treatment...(IDI R10)

Most of the respondents of IDIs and FGDs recognized the risk to mother's health posed by early pregnancy and childbirth. They identified such risks as weakness in mother, uterine prolapsed, uterine rupture and in some instances even death.

..Thank god I am safe I was very afraid during delivery because I thought I would die One of my friend expired during delivery at the age of 16 (IDI R22)

\section{Health effects on Baby:}

Most of the respondents were aware about the negative effect of teenage pregnancy and childbirth on baby.

My baby is small and he had congenital abnormality so doctor couldn't save him........... I had to abort the first time as well after two months so I felt very sad......... (IDI R 11)

Reproductive organs in Teenagers are not matured enough, so there is a high chance of premature birth and underweight babies being born. Moreover if they do not get special care during delivery they may die (FDGs)

\section{Prevention of teenage pregnancy:}

All of respondents realize that teenage pregnancy is a preventable social problem.

Because when the girl child is educated, she will understand the consequences of teenage pregnancy and childbirth, which will help reduce teenage pregnancy. Similarly, if they 
ISSN: 2362-1303 (Paper) | elSSN: 2362-1311(Online)

JOURNAL OF ADVANCED ACADEMIC RESEARCH (JAAR)

continue their education the chances of early marriage get low ultimately preventing teenage pregnancy and childbirth..... (FGDs).

\section{How to improve the outcomes of teenage pregnancy}

Most of the respondents believe that the situation can be improved by regular ANC check-up, proper intake of prescribed medicines, intake of nutritious food.

I had started ANC visit from second month of pregnancy and did regular check-

up....... I visited 10 times during my pregnancy..............Now my baby and me both are safe.....(IDI R1)

In my opinion, if a pregnant women includes nutritious diet in her meals both mother and child health will be improved.... But my family did not support me at the time pregnancy so I did not have access to nutritious diet that's why my baby was born underweight (IDIR 6)

All of the respondents considered love and affection is the most important during the period of pregnancy and childbirth.

\section{DISCUSSION}

Majority of the respondents of IDIs and FGDs perceived teenage pregnancy and childbirth as risk for both mother and baby. Though most of the respondents realized it as a social problem the trend of teenage marriage and pregnancy is still present in the society, country and even in world. Similar finding has been described in (UNFPA, 2005, NDHS, 2011, p.83).Moreover, a majority of respondents understood that causes of teenage pregnancy are culture, poverty, family pressure, family problems, pressure from husband, love marriage, sexual violence and lack of knowledge on family planning methods. Similar findings were found cited in journals (Kumar et al,2007, p. 41, Chedraui,2008).

Some of respondents understood that teenage pregnancy is an unavoidable problem so it doesn't matter whether the respondents are educated or not. Majority of the IDI respondents were from janajati (ethnic group), especially from that family whose sisters were teenage mother. Similar finding were described in other study (Monstad, Propper, \& Salvanes, 2011). Confirming the studies elsewhere, some of respondents mentioned that upbringing of the child was the most difficult part for them (Gyesaw,\&Ankomah, 2013).

Some of respondents also stated some advantages of teenage pregnancy, such as happiness and excitement in the family. Same has been found in other studies (Seamark \& Lings, 2004). 
ISSN: 2362-1303 (Paper) | elSSN: 2362-1311(Online)

JOURNAL OF ADVANCED ACADEMIC RESEARCH (JAAR)

A Majority of respondents however acknowledged teenage pregnancy and childbirth to cause more problems such as school dropout, lost job opportunity, increase poverty and ill health of mothers and baby. This is supported by the findings by cited authors (Monstad, Propper, \& Salvanes, 2011) (Wiemann, Rickert, Berenson, \& Volk, 2005, p. 352e4). (Acharya, 2010). (Dahl, 2010, p. 711).

A majority of respondents suffered many health problems during their pregnancy and childbirth, for example: anemia, premature delivery, operated delivery, prolonged labour. Their babies also suffered from problems like underweight, ill-health, jaundice, respiratory problems and were admitted in NICU. Similar findings had been shown elsewhere (Gortzak-Uzan, 2001,p. 393) (WHO, 2014). (Chen et al,2007, p.268).(Jolly, 2000, p. 964).

Most of the respondents realized that teenage pregnancy can be controlled through the means of education, good parental guidance, individual accountability of teenagers, awareness on consequences of teenage pregnancy and parent education. Very few mothers know about family planning. Similar finding was found in cited journal (Dangal, 2005, p.270)

A majority of respondents mentioned that regular ANC visit, adequate rest and sleep, intake of nutritious diet and fruits are helpful to improve the situation of teenage mothers and their babies. Confirming the findings from many studies (Iklaki, Inaku, Ekabua, Ekanem, \& Udo, 2012)(Gross, Alba, Glass, Schellenberg, \& Obrist, 2012)(Das, Dhukotta, Brook, \& Amu, 2007).

A majority of mothers and respondents from FGDs realized that parent, society, different organization and government have main responsibilities to prevent teenage pregnancy.

\section{CONCLUSION}

Teenage mothers faced many problems during pregnancy and childbirth. The finding suggests that there is a need to improve the situation of education in the various parts of the country and raise awareness regarding the consequences of teenage pregnancy. Chapters on teenage pregnancy and childbirth should be included in school curriculum. It also suggests that government should strictly implement the rules about the age of marriage.

\section{REFERENCES}


1. Acharya, D.R, Bhattarai, R., Amudha,P., Van Teijilingen, E., Chapman,G. (2010). Factors Associated with Teenage Pregnancy in South Asia: A systematic Review. Health Science Journal, 4(1), 3-14.

2. Basch, C. E. (2011). Teen Pregnancy and the Achievement Gap among Urban Minority Youth. Journal of School Health, 81(10), 614-618.

3. Brennan, L., McDonald, J., \& Shlomowitz, R. (2005). Teenage births and final adult height of mothers in India. Journal of Biosocial Science, 185-191.

4. Chedraui, P. (2004). Pregnancy among young adolscents: Trends, risk factors and maternal-perinatal outcome. 36, 3, 256-259.

5. Chen, X., Wen, S. W., Fleming, N., Yang, Q., \& Walker, M. C. (2007). Teenage pregnancy and congenital anomalies: which system is vulnerable? Human Reproduction and Embryology, 22(6), 1730-1735. doi:10.1093/humrep/dem043

6. Dahl, G. B. (2010). Early Teen Marriage and Future Poverty. Demography, 47(3), 689718.

7. Dangal,G. (2006). An Update on Teenage Pregnancy. Journal of Nepal Medical Association, 45(2), 267-272.

8. Das, S., Dhukotta, J. S., Brook, J., \& Amu, O. (2007). The impact of a dedicated antenatal clinic on the obstetric and neonatal outcomes in adolescent pregnant women. Journal of Obstetrics and Gynaecology, 75(5), 464 - 466. doi:10.1080/01443610701406042doi:10.1080/01443610701406042.

9. George, J. B. (2011). Nursing Theories the Basis For professional Nursing Practice (6th ed.). New Delhi, India: India Binding House.

10. Gortzak-Uzan, L., Hallak, M., Press, F., Katz, M., Shoham-Vardi, I. (2001). Teenage pregnancy: Risk factors for adverse perinatal outcome. Journal of Maternal-Fetal and Neonatal Medicine, 10, 6, 393-397.

11. Graneheim U.H., Lundman R. (2004). Qualitative Content Analysis in Nursing Research: Concepts, Procedure and Measures to Achieve Trustworthiness. Nurse Education Today, 24: 105-112.

12. Gross, K., Alba, S., Glass, T. R., Schellenberg, J. R., \&Obrist, B. (2012). Timing of antenatal care for adolescent and adult pregnant women in south-eastern Tanzania. BMC Pregnancy and Childbirth, 12(16), 1-12. Retrieved July 19, 2014, from http://www.biomedcentral.com/1471-2393/12/16

13. Gyesaw,N.Y.K.\&Ankomah,A. (2013). Experiences of pregnancy and motherhoodamong teenage mothers in a suburb of Accra,Ghana: a qualitative study. International Journal of Women's Health, 5,773-780. DOI:http://dx.doi.org/10.2147/IJWH.S51528

14. Iklaki, C. U., Inaku, J. U., Ekabua, J. E., Ekanem, E. I., \&Udo, A. E. (2012). Perinatal Outcome in Unbooked Teenage Pregnancies in the University of CalabarTeaching Hospital, Calabar, Nigeria. International Scholarly Research Network Obstetrics and Gynecology, 1-5. doi:10.5402/2012/246983 
15. Jolly, Mrcog, Sebire, Harris, Robinson, Regan. (Dec 2000). Obstretic Risk of Pregnancy in women less than 18 years old. Obstretic\& Gynaecology, 96 (6): 962-966. http://dx.doi.org/10.1016/S0029-7844(00)01075-9.

16. Kumar,A., Singh,T., Basu,S., Pandey,S., Bhargava, V.,. (2007). Outcome of teenage pregnancy. The Indian Journal of Paediatrics, 74(10), 927-939.

17. Monstad, K., Propper, C., \&Salvanes, K. G. (2011). Is teenage motherhood contagious? Evidence from a Natural Experiment. Bristol BS8 ITN, UK: Norwegian School of Economics. Retrieved on february 17, 2016, from http://www.bristol.ac.uk/cmpo

18. Nepal. Department of Health Services. (2011). Annual Report. Ministry of Health and Population, Government of Nepal, (Retrived date: 16 December 2015) from http://dohs.gov.np/sites/default/files/1/files/Annual_Report_2066_67.pdf

19. Paranjothy, S.,Broughton,H.,Adappa,R.,Fone,D.,. (2009). Teenage pregnancy : who suffers? Arch Dis Child;94, 239-245.

20. Sarah, A. J., \&Muthoni, N. F. (2012). De-stigmatizating Teenage Motherhood: Towards Achievement of Universal Basic Education in Kenya. Journal of Emerging Trends in Educational Research and Policy Studies (JETERAPS), 3(6), 887-892.

21. Seamark, C. J., \& Lings, P. (2004). Positive Experiences of Teenage Motherhood: A Qualitative Study. British Journal of General Practice, 54, 813-818.

22. UNFPA. (2005). Too young to die: Adolescent Maternal Deaths, Disabilities \& Unsafe Abortion.

23. UNFPA. Nepal. (2013). Adolescent Pregnancy. Retrived on 12 December 2015, from http://countryoffice.unfpa.org/nepal/?reports=8276, UNFPA.

24. WHO. (2008a). Why is giving special attention to adolescent important for achieving Millenium Development Goal? Fact Sheet. Retrieved February 17, 2016, from www.int/maternal_child_addolescent/events/2008/mdg5/adolescent_preg.

25. WHO. (2008b). MPS Notrs on Adolescent Pregnancy. Geneva: Department of Making Pregnancy Safer. 1 (1).Retrived on $10^{\text {th }}$ December 2015, from http://www.who.int/maternal_child_adolescent/documents/mpsnnotes_2 $1 \mathrm{r}$.

26. WHO. (2014). Maternal, newborn, child and adolescent health. Adolescent Pregnancy.

27. Wiemann, C. M., Rickert, V. I., Berenson, A. B., \& Volk, R. J. (2005). Are pregnant adolescents stigmatized by pregnancy? Journal of Adolescent Health, 36, 352.e1352.e7. doi:10.1016/j.jadohealth.2004.06.006 